\title{
Konstruksi Hukum Adat Pernikahan Masyarakat Melayu Palembang Berdasarkan Syar'iat Islam
}

\author{
Ahmad Fahmi \\ Kejaksaan Tinggi Sumatera Selatan \\ Afahmi577233@gmail.com
}

\begin{abstract}
Marriage is one of the tiers in the life of the society which called "stage a long the life cycle". The purpose of this research is to obtain the informationa about: First, The Customs Procedures of Marriage for Melayu Palembang People; Second, Islamic Law in Marriage Customs for Melayu Palembang People; Third, The Customs Culture of Marriage for Melayu Palembang People; and Fourth, The Islamic Construction of Marriage Customs for Melayu Palembang People. This Research is using Qualitative Research Methods with Law Sociologist approachment and Islamic Idea, which is focused to the implementation process of marriage based on Islamic and Culture law with performance goals that have been set. The Research several Data was obtained by using interview method which was done to the object of respondent. The results of this research show : First, The customs procedures of marriage for Melayu Palembang people, in the implementation, are use Islamic law however there are some choreography by itself such as pre-marriage and after marriage. The culture of marriage for Melayu Palembang people, is divided into four phases: Cultural phase pre-marriage, Cultural phase implementation of marriage, Cultural phase after marriage and pattern of settling after marriage. Second, Marriage Law in Islamic religious teachings with Matrial Law in the state law, in marriage ordinances of Melayu Palembang people in general can be said to have been aligned, in its implementation also in accordance with the rules and referral. Where as the references in the state law on marriage are Al Quran, Al Sunnah and Qaidah Fighiyah and Consesus of Muslims in Indonesia. Third, Contribution of customary law appears on before and after marriage where there are certain or dinances and there are certain ways to hold the marriage. The customary law of our country is the laws that suit the development of Islamic Society in Indonesia, customary marriage for Melayu Palembang people on its implementation is the application of Islamic Law Theory. Fourth, Construction of Islam in marriage maintained, that marriage has values that are preserved by Melayu Palembang people continuously. The value of faith in Islamic Marriage is a good act and behavior and can lead toward the marriage in the religion of Islam, namely to evoke marriage that enriches sakina, mawada, warahmah and barokah. The points contained in the religion of Islam contains the meaning and the bonding element that have a profund influence on customary marriage of Melayu Palembang people, because this bonds came from the power that comes from the Creator.
\end{abstract}

Keynote : Customs procedures of marriage, Islamic Law, Custom Marriage, and construction of Islam.

\begin{abstract}
Abstrak
Pernikahan merupakan salah satu babak tingkatan dalam hidup manusia yang disebut stages a long the life cycle. Tujuan penelitian adalah memperoleh informasi tentang: pertama, tata cara adat pernikahan masyarakat Melayu Palembang, Kedua, hukum Islam
\end{abstract}

online journals http://jurnal.radenfatah.ac.id/index.php/medinate 
dalam adat pernikahan melayu Palembang, Ketiga, adat dan budaya dalam pernikahan masyarakat melayu Palembang dan keempat, Konstruksi Islam dalam adat pernikahan masyarakat melayu Palembang. Penelitian ini menggunakan metode penelitian kualitatif dengan pendekatan sosiologi hukum dan pemikiran Islam, dimana Model ini memfokuskan pada proses pelaksanaan pernikahan berdasarkan hukum Islam dan Hukum adat dengan tujuan yang telah ditetapkan. Temuan penelitian ini menunjukan bahwa: pertama: tata cara adat pernikahan Masyarakat Melayu Palembang dalam pelaksanaannya menggunakan hukum Islam namun ada beberapa koreografi sendiri seperti pra nikah dan setelah nikah. Adat pernikahan Masyarakat Melayu Palembang dibagi dalam empat tahapan yaitu tahapan adat sebelum pernikahan, tahapan adat pelaksanaan pernikahan, tahapan adat setelah pernikahan dan pola menetap setelah menikah. Kedua, Hukum perkawinan dalam ajaran agama Islam dengan Undang-Undang tentang perkawinan, dalam tata cara perkawinan masyarakat melayu Palembang pada umumnya dapat dikatakan sudah sejalan, dalam pelaksanaannya pun sesuai dengan pijakan dan rujukan. Sedangkan yang menjadi pijakan dan rujukan dalam Undang-undang tentang perkawinan adalah Al Quran, Al Sunnah, Qaidah Fighiyah dan Konsensus (Ijma) Umat Islam di Indonesia. Ketiga, Kontribusi hukum adat tampak pada sebelum dan sesudah perkawinan dimana ada tata cara tertentu dan ada syarat tertentu untuk melangsungkan acara perkawinan. Hukum adat yang ada di negara kita adalah hukum yang sesuai dengan perkembangan masyarkat Islam di Indonesia, adat pernikahan masyarakat melayu Palembang pada pelaksanaannya merupakan aplikasi dari teori hukum Islam. Keempat, Konstruksi Islam dalam pernikahan mengandung makna bahwa perkawinan banyak tersemat dan dipertahankan oleh masyarakat melayu Palembang tanpa jeda. Nilai keimanan dalam perkawinan Islam adalah segala perbuatan dan tingkah laku yang baik dan dapat mengarah pada tujuan perkawinan dalam agama Islam, yakni mewujudkan pernikahan sakinah, mawadah, rahmah dan barokah.Intisari yang terkandung dalam agama Islam mengandung arti unsur dan Ikatan yang mempunyai pengaruh besar sekali terhadap pernikahan adat melayu Palembang, karena ikatan ini berasal dari suatu kekuatan yang berasal dari Sang Pencipta.

Kata Kunci: Tata cara pernikahan, Hukum Islam, adat pernikahan dan konstruksi Islam.

\section{Pendahuluan}

Pernikahan merupakan gerbang sah manusia dalam rangka meneruskan keturunan. Selain itu, pernikahan juga merupakan perintah agama untuk seluruh umat manusia. Didalam ajaran Islam, pernikahan mengandung nilai kepastian hukum yang berarti pernikahan harus dilaksanakan dengan memenuhi persyaratan-persyaratan tertentu, baik yang menyangkut kedua belah pihak maupun yang berhubungan dengan pelaksanaan perkawinan itu sendiri. Dalam hampir seluruh masyarakat atau suku bangsa di seluruh dunia, perkawinan merupakan masa peralihan yang dianggap sangat penting dalam hidup manusia.

Suku Palembang mewarisi peninggalan budaya yang mempunyai peradaban yang tinggi, selain itu juga khasanah budaya yang dimiliki suku Palembang sangat beragam. Ragam upacara adat-istiadat yang berkembang pada komunitas masyarakat Palembang, budaya dalam masyarakat melayu Palembang merupakan sarana sosialisasi yang sarat dengan nilai-nilai atau norma adat yang penting dalam masyarakat, maka tak heran bila masyarakat Melayu Palembang menghargai adat dan sangat menjunjung tinggi nilai-nilai 
dalam ikatan pernikahan. Meskipun dalam pelaksanaanya, proses upacara pernikahan telah bercampur baur dengan adat istiadat yang berlaku namun prosesi pernikahan suku Melayu sangat bernuansa Islami, hal itu terjadi karena dipengaruhi oleh agama yang dianut yaitu agama Islam.

Menurut hukum Islam perkawinan adalah perjanjian suci (sakral) berdasarkan agama antara suami dengan istri, berdasarkan hukum agama untuk mencapai satu niat, satu tujuan, satu usaha, satu hak, satu kewajiban, satu perasaan sehidup semati. Perkawinan adalah percampuran dari semua yang telah menyatu tadi. Nikah adalah akad yang menghalalkan setiap suami istri untuk bersenang-senang satu dengan yang lainnya (Jaza'iri, A.B.J, 2003: 688).

Menurut Izomiddin, hukum Islam yang ada pada saat ini adalah sesuatu yang telah mengalami perjalanan yang sangat panjang karena itu bagi setiap orang Islam memahami tarikh Tasyri adalah yang sangat penting. Dengan memahami hal ini setiap muslim akan dapat mengetahui dengan terang bagaimana sebenarnya hukum Islam itu berproses dan hal ini akan menambah wawasan dan menambah kedewasaan kita dalam beragama. Islam memiliki etika dalam pergaulan dan mengadakan perkenalan antara pria dan wanita, tahapan umum adalah proses ta'aruf atau perkenalan.

Pernikahan adalah suatu pristiwa yang amat sakral, hal ini tertera pada Pasal 1 Undang-Undang Nomor 1 Tahun 1974 menjelaskan bahwa: Perkawinan adalah ikatan lahir bathin antara seorang pria dengan seorang wanita sebagai suami istri dengan tujuan membentuk keluarga (rumah tangga) yang bahgia dan kekal berdasarkan Ketuhanan Yang Maha Esa (Perkawinan dan Kompilasi Hukum Islam ,2009: 7). Di Indonesia ketentuan yang berkenaan dengan perkawinan diatur dalam peraturan perundangan negara yang berlaku khusus bagi warga negara.

Negara sebagai penegak hukum menjadi sorotan penuh, pemimpin harus bertanggung jawab atas penegakan hukum baik itu hukum positif atau hukum Islam. ketika membicarakan hukum Islam di negara Indonesia ini belum pantas, sebab negara yang domisilinya mayoritas muslim hanya di penuhi oleh orang-orang Islam saja, tetapi hukum Islam tidak begitu di aplikasikan. Maka ini menjadi dasar penting mengenai konstruksi sumber hukum Islam di Indonesia, memang Islam di Indonesia diwarnainya beberapa instansi politik, sehingga sumber hukum Islam menjadi bermacam-macam.

Perkawinan menurut hukum adat yang dikemukakan oleh Hazairin adalah perkawinan merupakan rentetan perbuatan-perbuatan magis, yang bertujuan untuk menjamin ketenangan, kebahagiaan, dan kesuburan (Hazairin, 1951: 46).

Hadi kusumah membagi hukum adat menjadi tiga sifat yaitu:

"Pertama bersifat statis, artinya hukum adat selalu memelihara dan mempertahankan nilai-nilai luhur yang diajarkan oleh leluhurnya, sedangkan yang kedua bersifat dinamis, artinya hukum adat selalu mengikuti perubahan dan perkembangan zaman, sedangkan sifat yang ketiga adalah elastis, artinya hukum adat beradaptasi dengan berbagai keadaan dalam masyarakat, termasuk dengan kasus-kasus khusus dan menyimpang" (Hilman Hadikusumah, 1980: 59).

Pernikahan mempunyai akibat hukum terhadap hukum adat yang berlaku dalam masyarakat Melayu Palembang. Akibat hukum ini telah ada sejak sebelum perkawinan 
terjadi, misalnya dengan adanya proses melamar yang merupakan hubungan anak-anak (bujang-gadis) dan hubungan kedua orang tua, selain itu juga melibatkan keluarga dari pada calon suami-istri.

Adapun hukum adat yang mengatur tentang pernikahan adat Melayu Palembang, tersurat dalam Undang-Undang Simbur Tjahaja (Cahaya) Bab ke satu tentang Adat Bujang Gadis dan Kawin. Ada pun pada pasal 1 berbunyi: Djikalau budjang gadis hendak kawin mesti orang tua budjang dan orang tua gadis memberi tahu kepada Pesirah atau Kepala Dusun, itulah 'Terang'namanja', dan budjang bajar adat terangnja itu 'upah tuah'atau upah batin 3 ringgit (Undang-undang Simbur Tjahaya,1970: 7).

Hubungan hukum adat dengan hukum Islam dalam makna kontak antara kedua sistem hukum itu telah lama berlangsung di tanah air. Hubungan akrab dalam masyarakat tercermin dalam berbagai pepatah dan ungkapan di beberapa daerah,misalnya ungkapan dalam bahasa Aceh yang berbunyi: hukum ngon adat hantom cre, lagee zat ngon sipeut. Artinya hukum Islam dengan hukum adat tidak dapat dicerai pisahkan karena erat sekali hubungannya. Hubungan demikian juga terdapat di Minang Kabau yang tercermin dalam pepatah adat dan syara sanda menyanda, syara mengato adat memakai. Menurut Hamka makna pepatah ini adalah hubungan (hukum) adat dengan hukum Islam (syara') erat sekali, saling topang menopang, karena sesungguhnya yang dinamakan adat yang benar-benar adalah syara' itu sendiri (Hamka, 1974: 10). Dalam hubungan ini dapat dijelaskan bahwa adat dalam ungkapan ini adalah cara melaksanakan atau memakai syara' itu dalam masyarakat.

Suku Melayu Palembang atau Suku Palembang, dipengaruhi oleh pendatang lokal yang berurbanisasi dari desa-desa ke kota Palembang, seperti masyarakat Sekayu, Komering, Kayu Agung, Lahat, Muara Enim dan lain sebagainya, namun demikian pada kenyataannya suku Melayu Palembang, sangat berpegang teguh pada prinsip "sondok piyogo" atau dalam bahasa Indonesia artinya adat dipangku, syariat dijunjung”. Semboyan ini bermakna bahwa meskipun mereka sudah mengecap pendidikan tinggi, mereka harus tetap mempertahankan adat istiadat Palembang. Adapun semboyan tersebut hingga kini tetap dipegang teguh oleh suku Melayu Palembang. Maka, jika pun terjadi pernikahan tidak berdasarkan adat istiadat yang berlaku, maka biasanya masyarakat tidak merestuinya.

Berdasarkan uraian-uraian yang telah dikemukan sebelumnya dalam latar belakang di atas, maka menurut penulis ada beberapa hal membuat penelitian ini penting untuk dilakukan, yaitu: Pertama, belum pernah ada penelitian yang mengangkat tema Konstruksi Islam dalam hukum adat pernikahan masyarakat Melayu Palembang. Kedua, karena sekarang ini proses pernikahan adat masyarakat Melayu Palembang telah mengalami pergeseran (berubah). Adapun perubahan ini akibat dari penyebaran dari unsur-unsur kebudayaan (difusi), asimilasi (pembauran) dan alkulturasi, disamping faktor kurangnya penerapan nilai budaya dan ajaran Islam dan Adat Pernikahan masyarakat Melayu Palembang. Ketiga, dalam praktiknya masih terdapat konsep-konsep perkawinan yang masih menimbulkan kontroversi, dalam hal ini bagaimana menyikapi berbagai fakta dan fenomena tersebut. Keempat, adat perkawinan dalam budaya melayu Palembang terkesan rumit karena banyak tahapan yang harus dilalui. 


\section{KERANGKA TEORI}

\section{A. Konstruksi Islam}

Pengertian konstruksi dalam Kamus Besar bahasa Indonesia diartikan sebagai susunan kata (model, tata letak) suatu bangunan atau susunan dan hubungan kata dalam kelompok kata (Departemen Pendidikan Nasional, 2005: 590). Sedangkan menurut Uchjana definisi konstruksi adalah suatu konsep, yakni abstraksi sebagai generalisasi dari hal-hal yang khusus, yang dapat diamati dan diukur (Onang Uchjana Effendi, 1989:.264). Selajutnya menurut Berger, proses konstruksi sosial melalui tiga proses yaitu eksternalisasi, objektifitas dan internalisasi. Teori yang digunakan dalam penelitian ini adalah teori konsruksional yang digagas oleh Berger dan Luckman, dalam teori konstruksi sosial ini menegaskan bahwa:

"Agama sebagai bagian dari kebudayaan merupakan konstruksi manusia ini artinya, bahwa terdapat proses dialektika antara masyarakat dengan berada dalam teks dan norma. Teks atau norma tersebut mengalami proses internalisasi ke dalam diri individu karena telah diinterpretasi oleh manusia menjadi guidance atau way of life. Agama juga mengalami proses eksternalisasi karena agama menjadi sesuatu yang shared di masyarakat (Berger P.L dan Luckman, 1990: 22).

Konstruksi menurut Supadie mengandung arti, bahwa apakah sejarah berlaku dahulu yang masih berkaitan disusun, dipahami, dihayati dan dicerna (Didiek Ahmad Supadie,dkk., 2012: 4). Sedangkan konstruksi teori adalah susunan atau bangunan dari suatu pendapat asas-asas atau hukuman mengenai sesuatu yang antara satu dan lainnya saling berkaitan sehingga membentuk suatu bangunan (https://mediacom837.wordpress.com/2016/04/08.). Sedangkan menurut Kamus Umum Bahasa Isndonesia Islam adalah agama yang diajarkan oleh Nabi Muhammad SAW.

Jadi Konstruksi Islam adalah susunan atau bangunan dari suatu pendapat, asas-asas atau hukum mengenai sesuatu yang antara satu dan lainnya saling berkaitan, sehingga membentuk suatu susunan atau bangunan berdasarkan nilai, norma-norma dan hukum dalam agama Islam.

Menurut Abudin, Konstruksi agama adalah suatu upaya memeriksa, mempelajari meramalkan dan memahami secara seksama atau bangunan dasar-dasar atau hukumhukum dan ketentuan lainnya yang diperlukan untuk melakukan penelitian terhadap bentuk pelaksanaan ajaran agama sebagai dasar pertimbangan untuk, meramalkan dan, memahami secara seksama atau bentuk pelaksanaan ajaran agama sebagai dasar pertimbangan untuk mengembangkan pemahaman ajaran agama sesuai tuntutan zaman (Nata Abudin, 2004:.167).

Selanjutnya Palomo mendefinisikan "konstrusi sosial atas realitas (sosial construction of reality) sebagai proses sosial melalui tindakan dan interaksi dimana individu menciptakan secara terus menerus suatu realita yang dialami bersama (Margaret Paloma, 2000: 301. Sedangkan Abdullah berpendapat, "Konstruksi Sosial Budaya terbentuk dari sejarah pengalaman manusia yang diinterpretasikan dan dimaknai berdasarkan pengetahuan yang dimiliki (Irwan Abdullah, 2006:.30). 
Dengan demikian, yang dimaksud dengan realita sosial adalah hasil dari sebuah konstruksi sosial yang diciptakan oleh manusia itu sendiri. Realitas sosial adalah sesuatu yang tersirat di dalam pergaulan sosial yang diungkapkan secara sosial melalui konstruksi sosial dibangun dengan cara mendefinisikan tentang kenyataan atau realitas komunikasi bahasa, kerjasama melalui bentuk-bentuk organisasi sosial dan seterusnya. Realitas sosial ditemukan dalam pengalaman intersubjektif, sedangkan pengetahuan mengenai realitas sosial adalah berkaitan dengan kehidupan bermasyarakat dengan segala aspeknya, meliputi ranah kognitif, psikomotorik, emosional dan intuitif.

Manusia yang hidup dalam konteks sosial tertentu melakukan proses interaksi secara simultan dengan lingkungannya. Masyarakat hidup dalam dimensi-dimensi dan realitas objektif yang dikonstruk melalui momen eksternalisasi dan objektivasi dan dimensi subjektif yang dibangun melalui momen internalisasi. Baik momen eksternalisasi, objektivasi maupun internalisasi tersebut akan selalu berproses secara dialektik dalam masyarakat.

\section{B. Konsep Pemikiran Islam Dalam Pernikahan}

Pada tataran filsafat, pernikahan memiliki dimensi yang sangat luas, fososofi pernikahan lebih luas dari hukum pernikahan, sementara nilai adalah dasar dari pembentukan norma-norma hukum. Hukum sendiri merupakan kesepakatan yang dilandasi oleh nilai-nilai yang terukur (Nasaruddin Umar, 2010: ). Islam adalah agama menyelamatkan manusia menggapai jalan yang lurus, membawa misi nilai-nilai kemanusiaan, seperti nilai keadilan, kemaslahatan, kesetaraan laki-laki dan perempuan, dan tidak mengenal diskriminasi ras, suku dan agama. Islam telah memberikan konsep yang jelas tentang tata cara ataupun proses sebuah pernikahan yang berlandaskan Al-Qur`an dan As-Sunnah yang shahih, dengan rincian sebagai berikut:

Pertama, adalah mengenal calon pasangan hidup, sebelum seorang lelaki memutuskan untuk menikahi seorang wanita, tentunya ia harus mengenal terlebih dahulu siapa wanita yang hendak dinikahinya, begitu pula sebaliknya si wanita tahu siapa lelaki yang berhasrat menikahinya. Tentunya proses kenal-mengenal ini tidak seperti yang dijalani orang-orang yang tidak paham agama, sehingga mereka menghalalkan pacaran atau pertunangan dalam rangka penjajakan calon pasangan hidup, kata mereka.

Kedua, pacaran dan pertunangan haram hukumnya tanpa kita sangsikan. Adapun mengenali calon pasangan hidup di sini maksudnya adalah mengetahui siapa namanya, asalnya, keturunannya, keluarganya, akhlaknya, agamanya dan informasi lain yang memang dibutuhkan. Ini bisa ditempuh dengan mencari informasi dari pihak ketiga, baik dari kerabat pihak lelaki atau pihak wanita ataupun dari orang lain yang mengenali lelaki atau wanita. Yang perlu menjadi perhatian, hendaknya hal-hal yang bisa menjatuhkan kepada fitnah (godaan setan) dihindari kedua belah pihak seperti bermudah-mudahan melakukan hubungan telepon, sms, surat-menyurat, dengan alasan ingin ta aruf (kenalmengenal) dengan calon suami/istri.

Jangankan baru ta'aruf, yang sudah resmi meminang pun harus menjaga dirinya dari fitnah. Karenanya, ketika Syaikh Shalih bin Fauzan bin Abdillah Al-Fauzan hafizhahullah ditanya tentang pembicaraan melalui telepon antara seorang pria dengan seorang wanita yang telah dipinangnya, beliau menjawab, Tidak apa-apa seorang laki-laki 
berbicara lewat telepon dengan wanita yang telah dipinangnya, bila memang pinangannya telah diterima dan pembicaraan yang dilakukan dalam rangka mencari pemahaman sebatas kebutuhan yang ada, tanpa adanya fitnah. Namun bila hal itu dilakukan lewat perantara wali si wanita maka lebih baik lagi dan lebih jauh dari keraguan/fitnah. Adapun pembicaraan yang biasa dilakukan laki-laki dengan wanita, antara pemuda dan pemudi, padahal belum berlangsung pelamaran diantara mereka, namun tujuannya untuk saling mengenal, sebagaimana yang mereka istilahkan, maka ini mungkar, haram, bisa mengarah kepada fitnah serta menjerumuskan kepada perbuatan keji.

Jadi kedua insan manusia harus berhimpun menjadi satu kesatuan melalui sebuah perkawinan yang disebut rumah tangga, sehingga perkawinan menjadi sumber kebahagiaan.

Selain itu tujuan pernikahan sebagaimana disebutkan dalam salah satu ayat dalam Al-Quran adalah (artinya) : Dan di antara tanda-tanda kekuasaan-Nya ialah Dia menciptakan untukmu istri-istri dari jenismu sendiri, supaya kamu cenderung dan merasa tenteram kepadanya, dan dijadikan-Nya di antara kamu rasa kasih sayang (Q.S ar-Rum (30) ayat: 21).

Ulama tafsir menyatakan bahwa as-sakinah adalah suasana yang damai yang melingkupi rumah tangga yang bersangkutan, masing-masing pihak menjalankan perintah Allah SWT dengan tekun, saling menghormati, dan saling toleransi. Dari suasana assakinah tersebut akan muncul rasa saling mengasihi dan menyayangi (almawaddah), sehingga rasa tanggung jawab kedua belah pihak semakin tinggi. Selanjutnya, para musafir mengatakan bahwa dari as-sakinah dan al-mawaddah inilah nanti muncul ar-rahmah, yaitu keturunan yang sehat dan penuh berkat dari Allah SWT, sekaligus sebagai pencurahan rasa cinta dan kasih.Sakinah (as-sakinah), mawadah (al-mawaddah), dan rahmat (ar-rahmah).

Perkawinan merupakan salah satu sunnatullah yang berlaku pada semua makhluk Tuhan. Demi menjaga kehormatan dan martabat kemuliaan manusia, Allah mengadakan hukum sesuai dengan martabatnya, sehingga hubungan antara laki-laki dan perempuan diatur secara terhormat dan berdasarkan saling meridhai, dengan upacara ijab Kabul sebagai adanya rasa ridha-meridhai dan dengan dihadiri para saksi yang menyaksikan bahwa pasangan laki-laki dan perempuan telah saling terikat.

\section{Hukum Islam Dalam Pernikahan}

Sumber hukum Islam adalah Al Qur·an, Hadits, Ijma' dan Qiyas. Keempat sumber hukum Islam ini tidak diragukan lagi kebenarannya. Namun ada diantara sumber hukum Islam yang empat ini sekarang difahami dengan luas, maka menjadikan sumber hukum yang melahirkan fatwa-fatwa. Sumber hukum Islam yang berlabel Ijma' ini harus difahami dengan baik, kapan ijma bisa digunakan, bisa di jadikan rujukan-rujukan masyarakat, mengingat masyarkat Indonesia tidak mencari rujukan kepada yang aslinya (alQuran dan Hadits) tetapi cukup merujuk kepada sumber ijma' tadi. Hal ini memang dipengaruhi oleh kekurangan dari ilmu untuk mendalaminya.

Dalam perjanjian suatu perkawinan telah sejak semula ditentukan oleh hukum (pasal 6 UU No 1 Tahun 1974 ayat ( 2): perkawinan harus didasarkan atas persetujuan kedua calon mempelai). Oleh karena itu pihak pria dan pihak wanita tidak bisa 
menyimpang dari ketentuan-ketentuan dan akibat-akibat yang timbul dari suatu perkawinan. Mereka harus taat pada peraturan-peraturan hukum yang berlaku, mengenai hak-hak dan kewajiban masing-masing pihak selama dan sesudah hidup bersama itu berlangsung juga mengenai kedudukan dalam masyarakat dari anak-anak keturunannya. Suami istri tidak leluasa menetukan sendiri syarat-syaratnya melainkan terikat kepada peraturan-peraturan yang telah ditentukan.

Substansi keabsahan perkawinan adalah lebih penting dari pada keberagaman prosedur, ini merupakan salah satu konsekwensi kentalnya unsur agamawi dari struktur Undang-Undang perkawinan. Tujuan Undang-Undang perkawinan menciptakan unifikasi secara utuh.

\section{Hukum Adat dan Budaya Dalam Pernikahan}

Menurut Tolib Setiady, hukum pelanggaran adat ialah aturan-aturan hukum adat yang mengatur peristiwa atau perbuatan kesalahan yang berakibat pada terganggunya keseimbangan masyarakat sehingga perlu diselesaikan (dihukum) agar keseimbangan masyarakat tidak terganggu (Tolib Setiady, 2009: 345).

Seorjono Soekanto menyatakan bahwa hukum adat merupakan kompleks adat istiadat yang tidak dikitabkan, tidak dikodifisir dan bersifat paksaan, tapi mempunyai akibat hokum (Soerjono Soekanto, t.t.: 20). Sedangkan Ter Haar dengan teori Beslisingenleer-nya menyatakan bahwa, tiada suatu alasan apapun umtuk menyebut sesuatu dengan nama hukum selain dari apa yang diputuskan sebagai hukum oleh pejabatpejabat masyarakat yang bertugas dalam menetapakan keputusan-keputusan hokum (Ter Haar, 1997: 275).

Emile Durkheim berpendapat bahwa reaksi sosial yang berupa penghukuman atau sanksi sangat perlu dilakukan untuk merawat agar tradisi-tradisi kepercayaan adat menjadi tidak goyah, sehingga kesetabilan masyarakat dapat terwujud (Emile Durkheim, t.t.: 502).

Beberapa daerah lingkungan hukum adat di Indonesia mempunyai jenis- jenis reaksi adat (adat koreksi/sanksi adat) terhadap pelanggaran hukum adat, misalanya:

1. Pengganti kerugian kerugian imateriil dalam beberapa rupa seperti paksaan menikahi gadis yang dicemarkan.

2. Bayaran uang adat kepada yang terkena, yang berupa benda sakti sebagai pengganti kerugian rohani.

3. Penutup malu, permintaan maaf.

4. Berbagai hukuman badan hingga hukuman mati.

5. Pengasingan dari masyarakat serta meletakkan orang itu di luar tata hokum (Soepomo, 1893: 20).

Dari beberapa pengertian hukum adat diatas, dapat disimpulakan bahwa Ciri utama yang melekat pada hukum adat terletak pada sanksi atau akibat hukum. Hukum Adat di Indonesia pada umumnya dalam perkawinan bukan saja berarti sebagai perikatan perdata tetapi juga merupakan "Perikatan Adat" dan sekaligus merupakan perikatan kekerabatan dan kekeluargaan. Jadi terjadinya suatu ikatan perkawinan bukan semata-mata membawa akibat terhadap hubungan-hubungan keperdataan, seperti hak dan kewajiban suami isteri, harta bersama kedudukan anak, hak dan kewajiban orang tua, tetapi juga menyangkut hubungan-hubungan adat istiadat, kewarisan kekeluargaan, dan kekerabatan dan 
ketetanggaan serta menyangkut upacara-upacara adat dan keagamaan. Begitu juga menyangkut kewajiban mentaati perintah dan larangan keagamaan, baik dalam hubungan manusia dengan Tuhannya (Ibadah) maupun hubungan manusia dengan manusia (Mu'Amalah) dalam pergaulan hidup agar selamat didunia dan selamat di Akhirat.

\section{E. Aspek Religius dan Aspek Sosial Hukum Islam}

Pangertian aspek menurut Kamus Umum Bahasa Insdonesia adalah "Segi pandangan terhadap suatu hal atau peristiwa atau pandangan terhadap terjadinya suatu peristiwa dari permulaan sampai akhir". Aspek dan nilai dalam kehidupan manusia sangat penting keberadaannya. Lehaly berpendapat bahwa:" manusia adalah makhluk paradoksal dan penuh kontras, terbatas dan terbuka pada kenyataan yang tidak terbatas, terkondisi dan bebas, kodrati dan budayani, fisik dan rohani, individual dan sosial" (Louis Leahly, 1984: 995). Sedangkan Notonagoro membagi nilai menjadi 3 (tiga) macam aspek yaitu :1.Nilai material, yaitu segala sesuatu yang berguna bagi kehidupan jasmani manusia atau kebutuhan material ragawi manusia.2.Nilai vital, yaitu segala sesuatu yang berguna bagi manusia untuk dapat mengadakan aktivitas dan kegiatan. 3.Nilai kerohanian, yaitu segala sesuatu yang berguna bagi rohani manusia, nilai kerohanian ini dapat dibedakan atas empat macam yaitu nilai kebenaran, nilai keindahan, nilai kebaikan dan nilai religious (Notonagoro, 1975: 90).

Manusia sebagai makhluk budaya tentu pada dirinya mempunyai kesadaran tentang nilai,karena dalam budaya meliputi segala sesuatu sebagaimana adanya (das sein), serta meliputi pula dunia kaharusan (das sollen). Oleh karena itu manusia pada dasarnya menerima apa yang ada akan tetapi disamping itu mencari apa yang seharusnya ada.

Adapun Aspek-aspek hukum Islam menurut Daud Ali dibagi menjadi dua belas yaitu:

1. Nafyul Haraji = meniadakan kepicikan

2. Qillatul taklif (hukum yang memberatkan mukallaf)

3. Membina hukum dengan menempuh jalan tadarruj, tahap dengan tahap, satudemi sat u.

4. Sejalan dengan kemaslahatan manusia.

5. Mewujudkan keadilan yang merata.

6. Menutup segala jalan yang menuju kejahatan.

7. Mendahulukan akal atas dhahir nash.

8. Membolehkan kita mempergunakan segala yang indah.

9. Menetapkan hukum berdasarkan 'uruf yang berkembang dalam masyarakat.

10. Keharusan / kewajiban kita mengikuti segala sabda Nabi SAW. Yang disabdakan s ebagai syariat, tidak diwajibkan kita mengikuti sabda sabda beliau atau anjuran anjur an beliau yang berhubungan dengan keduniaan yang berdasarkan ijtihadnya.

11. Masing-masing orang yang berdosa hanya memikul dosanya sendiri

12. Syara' yang menjadi sifat dzatiyah Islam (Mohammad Daud Ali, 1990: 78).

Hukum Islam menerima perubahan di bidarig wasilah dan kenyataan, selama perubahan ini mewujudkan tujuan hukum dengan jalan yang paling mudah. 


\section{Metode Penelitian}

Kategori penelitian ini adalah penelitian kualitatif, Menurut Bogdan dan Taylor (dalam moleong) metode kualitatif merupakan sebuah prosedur penelitian yang menghasilkan data deskriptif berupa kata-kata tertulis maupun lisan dari orang-orang maupun perilaku yang dapat diamati (Bogdan dan Taylor, t.t.: 104). Penelitian ini menggunakan metode deskriptif, dikatakan deskriptif karena penelitian ini mencoba mengungkapkan kejadian yang sedang berlangsung, bertalian dengan penelitian deskriptif. Pendekatan Penelitian ini adalah pendekatan sosiologis, filosofis dan yuridis, dengan melakukan penelitian ini dapat diperoleh pendekatan optimal untuk mengetahui penerapan hukum Islam dalam tata cara adat pernikahan masyarakat Melayu Palembang, sedangkan pemikiran Islam dan hukum adat menggunakan pendekatan sosiologi kebudayaan dengan tujuan untuk menggambarkan nilai filosofis, jejak sejarah dan tradisi. Sampel Sumber Data (Informan Penelitian) Subyek dan Informan dalam penelitian ini menjadi unit analisis, adapun yang menjadi subyek dan informan adalah Kepala Dinas Kebudayaan Palembang, Kepala Dinas Pariwisata Kota Palembang, Ketua Dewan Kesenian Palembang, Tokoh masyarakat Palembang yang diwakili oleh Sultan Palembang dan Hakim pada Pengadilan Agama Palembang. Data yang didapat dari sumber data/informan penelitian merupakan gambaran atau hasil yang diperoleh peneliti di lapangan. Data yang dikumpulkan berupa uaraian, narasi juga penjelasan dari sumber data, baik pernyataan secara lisan, tulisan serta dokumen-dokumen pendukung penelitian. Data ini dicatat melalui catatan tertulis yang merupakan hasil usaha gabungan dari kegiatan melihat, mendengar dan bertanya. Teknik Analisis Data dilakukan dengan mengikuti prosedur sebagaimana yang disarankan oleh nasution, yaitu: (a) reduksi data, (b)display data dan(c) pengambilan kesimpulan dan verivikasi (S.Nasution, 1992: 129). Pemeriksaan Keabsahan Data melalui tahapan-tahapan: (1) tahap orientasi, (2) tahap eksplorasi, (3) tahap member check.

\section{Hasil dan Diskusi}

\section{A. Tata Cara Adat Permikahan Masyarakat Melayu Palembang}

Tahapan Adat Sebelum Acara Perkawinan.

\section{Madik}

Tahap awal yang dilakukan saat memulai rangkaian prosesi pernikahan Masyarakat Melayu Palembang adalah acara madik, yang berarti mendekati atau pendekatan. Ini semacam proses penyelidikan keberadaan sang gadis oleh utusan keluarga pihak pria. Tujuannya untuk mengetahui asal-usul, silsilah keluarga, sekaligus mencari tahu apakah gadis itu sudah ada yang punya atau belum.

Madik adalah proses penyelidikan yang dilakukan keluarga sang bujang terhadap sang gadis, penyelidikan ini dilakukan untuk mengetahui keadaan,sifat dan kepandaian sang gadis, juga keluarganya. Seperti cantikah dia, sopankah dia,pandaikah dia, pandaikah dia memasak dan mengatur rumah tangga,mengaji dan lain-lain.

Untuk melakukan madik biasanya keluarga sang bujang mengutus seorang wanita yang mereka percaya untuk brkunjung ke rumah ke rumah orang tua sang gadis. Wanita ini disebut kepalak rasan . 
Di masa lalu sering terjadi perkawinan antara bujang dan gadis yang sebelumnya tidak saling mengenal. Masyarakat Palembang menyebut perkawinan ini dengan istilah rasan tuo. Dapat pula terjadi,sang bujang sudah pernah melihat sang gadis dan jatuh cinta pada pandangan pertama. Untuk mendapatkan sang gadis, bujang akan meminta orang tuanya untuk melamar sang gadis, sebelum menyetujui maksud bujangnya, terlebih dahulu orang tua akan melakukan madik.

Menurut tata cara adat perkawinan suku Melayu Palembang dan kebanyakan suku lainnya di Sumatera Selatan,perkawinan bukan hanya berfungi pengaturan perilaku seks sepasang anak manusia,tetapi perkawinan berarti pula penyatuan dua keluarga besar,penyesuaian perilaku,penyesuaian adat istiadat dan lain-lain.

Bila ditarik garis merah antara pernikahan adat Melayu Palembang dengan pernikahan Islam memiliki banyak unsur kesamaan. Misalnya pada prosesi "madik" (http://karimsh.multiply.com/journal/item/12), Madik itu berasal dari bahasa jawa kawi, yang berarti mendekat atau pendekatan. Madik adalah suatu proses penyelidikan atas seorang perempuan yang dilakukan oleh utusan pihak keluarga laki-laki. Pertama-tama, keluarga calon mempelai laki-laki mengadakan observasi (pengamatan) terhadap calon mempelai wanita dan keluarganya. Begitu juga sebaliknya, keluarga calon mempelai perempuan mengadakan observasi pula terhadap calon mempelai laki-laki dan keluarganya,dengan kata lain madik adalah proses penyelidikan atas seorang gadis yang dilakukan oleh utusan keluarga pria. Tujuannya tentu untuk berkenalan, mengetahui asalusul, silsilah keluarga, dan mencari tahu apakah gadis itu sudah ada yang meminang atau belum.

\section{Nyenggung}

Apabila proses madik ini semua pihak sudah setuju maka proses selanjutnya adalah nyenggung. Dalam proses nyenggung biasanya dilaksanakan pada bulan puasa, selain itu juga saling mengantarkan makanan untuk buka puasa (bukaan), dari dua bulan sebelumnya proses ini sudah dijalani dan tidak putus, jadi silaturahmi tetap terjaga.

Nyenggung merupakan tahapan selanjutnya untuk mengetahui tentang sang gadis sudah ada yang melamar atau sudah tunangan.Tahap menyenggug dilakukan bila proses madik telah terlaksana, yang artinya memasang "pagar". Tujuannya agar gadis itu tidak dapat diganggu oleh senggung (arti kiasan, berarti sejenis hewan musang), yang arti

sesungguhnya tidak diganggu oleh pria lain. Acara ini untuk menunjukkan keseriusan calon pengantin pria.

Islam adalah agama budi pekerti yang tinggi yang mewajibkan sebuah perkawinan sebagai sarana untuk mencari sifat-sifat mulia,motivasi yang bagus dan budi pekerti yang mulia.

Seorang wanita adalah manusia, dan yang paling indah dari padanya adalah kemanusiaannya,hakikat yang cemerlang dan sifat-sifatnya yang menarik, sebaik-baik yang ada pada diri seseorang adalah kemanusiaaannya yang tinggi. Jika wanita mempunyai kemanusiaan yang tinggi, maka ia mempunyai keindahan yang sebenarnya.

Tahapan ini dalam adat adalah keluarga pria datang mengirimkan utusan ke rumah sang gadis sambil membawa tenong/sangkek yaitu anyaman bambu berbentuk bulat atau persegi empat yang dibungkus dengan kain batik bersulam benang emas. Tenong diisi 
dengan aneka bahan makanan seperti telor, terigu, mentega, yang disesuaikan dengan keadaan keluarga sang gadis.

\section{Nuku atau melamar}

Bila proses nyengguk telah mencapai sasaran, maka kembali keluarga dari pihak pria berkunjung dengan membawa tenong sebanyak 3 buah, masing-masing berisi terigu, gula pasir dan telur itik. Pertemuan ini sebagai tanda bahwa kedua belah pihak keluarga telah "nemuke kato" serta sepakat bahwa gadis telah 'diikat' oleh pihak pria. sebagai tanda ikatan, utusan pria memberikan bingkisan pada pihak wanita berupa kain, bahan busana, ataupun benda berharga berupa sebentuk cincin, kalung, atau gelang tangan.

Islam telah menuntun setiap Muslim Laki-laki atau wanita cara memilih calon pendamping hidup yang baik, jika tuntunan ini diikuti, pasti pelakunya akan mendapatkan kebahagiaan dalam rumah tangganya.

Islam adalah agama yang fitrah, sedikitpun tidak pernah mengenal lahiriah yang palsu atau tradisi yang dibuat-buat, karena cara yang demikian tisak seiring dengan takwa dan kepentingan masyarakat.

Hubungan perkawinan adalah sama dengan apa saja yang harus disetujui oleh kedua belah pihak. Karena itu masing-masing pihak diberi hak yang sama untuk menutarakan kehendaknya dalm persetujuan yang telah disepakati oleh keduanya.

Intinya dalam tahapan ini adalahmembicarakan tentang permintaan keluarga calon penganten perempuan dan syarat adat lainnya.

\section{Berasan}

Dalam tahapan berasan ini maka menurut syariat agama Islam, kedua belah pihak sepakat tentang jumlah mahar atau mas kawin, Sementara menurut adat istiadat, kedua pihak akan menyepakati adat apa yang akan dilaksanakan, apakah adat Berangkat Tigo Turun, adat Berangkat duo Penyeneng, adat Berangkat Adat Mudo, adat Tebas, ataukah adat Buntel Kadut, dimana masing-masing memiliki perlengkapan dan persyaratan tersendiri.

Berasan merupakan perundingan yang dilakukan beberapa hari sesudah nuku atau melamar, dan merupakan penentu untuk berlanjut ke $t$ ahapan selanjutnya. Berasan dari bahasa Melayu artinya bermusyawarah, yaitu bermusyawarah untuk menyatukan dua keluarga menjadi satu keluarga besar. Pertemuan antara dua pihak keluarga ini dimaksudkan untuk menentukan apa yang diminta oleh pihak si gadis dan apa yang akan diberikan oleh pihak pria. Pada kesempatan itu, si gadis berkesempatan diperkenalkan kepada pihak keluarga pria. Biasanya suasana berasan ini penuh dengan pantun dan basa basi. Setelah jamuan makan, kedua belah pihak keluarga telah bersepakat tentang segala persyaratan perkawinan baik tata cara adat maupun tata cara agama Islam. Pada kesempatan itu pula ditetapkankapan hari berlangsungnya acara "mutuske kato". Dalam tradisi adat Palembang dikenal beberapa persyaratan dan tata cara pelaksanaan perkawinan yang harus disepakati oleh kedua belah pihak keluarga, baik secara syariat agama Islam, maupun menurut adat istiadat.

\section{Mutus kato}

Upacara memutuskan kata-kata penentuan dan membahas semua persyaratan. Mutuske kato/mutus rasanmempunyai arti memutuskan kata-kata penentuan apakah 
pemberian kepada calon pengantin perempuan, sesuai dengan yang telah disepakati waktu berasan. Berupa apakah maskawinnya, berapa suku mas kawinnya, berapa jumlah uang asapnya, berapa hidangan pengiringnya, songketnya berapa turun, gegawaannya berapa lusin, tanggal dan bulan penetapan pernikahan akan dilangsungkan.

Islam menilai peminangan sebagai salah satu sarana untuk menenali sifat-sifat lahiriah calon pendamping hidup yang dapat menambah kemantapan untuk menikahi wanita. Peminangan hanya berlaku dalam waktu yang terbatas (tidak lama). Karena itu setelah laki-laki yang meminang merasa mantap dan cocok dengan wanita yang dipinangnya, sebaiknya ia melakukan pernikahan dengan wanita tersebut jangan menunggu waktu terlalu lama, karena dikhawatirkan terjadinya sesuatu yang tidak diinginkan terhadap salah satu dari keduanya.

Jika pada tahapan adat sebelummnya, kepalak rasan hanya didampingi kaum perempuan, disaat mutus kato kepalak rasan membawa rombongan yang jumlahnya lebih banyak dari tahapan adat sebelumnya. Rombongan terdiri dari perempuan dan laki-laki didampingi kepala kampung atau lurah setempat, juga ahli adat (tetuo-tetuoadat). Namun pembicaraan (dialog) tetap dilakukan oleh kaum perempuan, sementara kepala kampung mencatat apa yang telah menjadi keputusan, baik berupa pemberian maupun tanggal pernikahan.

Keluarga calon mempelai pria datang membawa tujuh buah tenong berisi gula pasir, terigu, telor itik, pisang dan buah-buahan ke rumah calon pengantin wanita, dan menyerahkan persyaratan adat yang disepakati saat acara berasan. Acara diakhiri dengan doa memohon keselamatan. Lalu calon pengantin wanita melakukan sungkem pada calon mertua. Biasanya calon mertua akan memberikan perhiasan emas kepada calon menantunya.

Sebagai balasan, saat rombongan calon pengantin pria pulang, tujuh tenong yang dibawa tadi, dibalas oleh pihak keluarga calon pengantin wanita dengan isian aneka jajanan dan kue.

\section{Nganter Mas Kawin}

Tahapan adat nganter mas kawin dapat dilakukan seminggu sebelum hari pernikahan,dapat juga dilakukan pada saat menjelang akad nikah atau di hari munggah. Nganter mas kawin merupakan tata cara adat suku Palembang, disebut juga anter-anteran atau gegawean. Mas kawin berupa mas murni yang jumlahnya tergantung dari kesepakatan saat mutus kato.

Keringanan jumlah mas kawin tergantung kepada kondisi ekonomi laki-lakinya. Adakalanya sejumlah uang dinilai mudah oleh seseorang tetapi dinilai berat oleh yang lain, hal ini dikarenakan perbedaan dalam kondisi ekonominya. Sedangkan yang menjadi dasar bahwa tinggi mas kawin tergantung kepada kemampuan seseorang adalah target yang diberikan oleh Rasullullah.

\section{Nganterke Belanjo}

Prosesi nganterke belanjo biasanya dilakukan sebulan atau setengah bulan bahkan beberapa hari sebelum acara Munggah. Prosesi ini lebih banyak dilakuakn oleh kaum wanita, sedangkan kaum pria hanya mengiringi saja. Uang belanja (duit belanjo) dimasukan dalam ponjen warna kuning dengan atribut pengiringnya berbentuk manggis. 
Hantaran dari pihak calon mempelai pria ini juga dilengkapi dengan nampan-nampan paling sedikit 12 buah berisi aneka keperluan pesta, antara lain berupa terigu, gula, buahbuahan kaleng, hingga kue-kue dan jajanan. Lebih dari itu diantar pula'enjukan' atau permintaan yang telah ditetapkan saat mutuske kato, yakni berupa salah satu syarat adat pelaksanaan perkawinan sesuai kesepakatan. Bentuk gegawaan yang juga disebut masyarakat Palembang 'adat ngelamar' dari pihak pria (sesuai dengan kesepakatan) kepada pihak wanita berupa sebuah ponjen warna kuning berisi duit belanjo yang dilentakan dalam nampan, sebuah ponjen warna kuning berukuran lebih kecil berisi uang pengiring duit belanjo, 14 ponjen warna kuning kecil diisi koin-koin logam sebagai pengiring duit belanjo, selembar selendang songket, baju kurung songket, sebuah ponjen warna kuning berisi uang, timbang pengantin, 12 nampan berisi aneka macam barang keperluan pesta, serta kembang setandan yang ditutup kain sulam berenda.

Pada tahapan pra nikah ini menunjukan tata krama adat yang luhur dan sesuai dengan norma-norma keislaman. Ada nilai kebersamaan, musyawarah, saling menghargai dan kesungguhan dalam menjalin rumah tangga yang baik sesuai dengan adat tapi tidak lepas dari tuntunan agama.

\section{Tahapan Adat Pelaksanaan Upacara Perkawinan}

Tahapan pelaksanaan upacara pernikahan yang berkaitan dengan hukum Islam adalah

\section{a. Akad nikah.}

Tahapan selanjutnya adalah akad nikah dan akad nikah biasanya dilaksanakan di rumah pengantin laki-laki. Menurut adat kalau menikah di rumah penganti wanita diistilahkan dengan kawin tumpang dan keluarga merasa terhina, tetapi pada saat sekarang tidak lagi seperti itu. Sedangkan di rumah pengantin perempuan sehari sebelum akad nikah dilakukan khataman al Qur'an.

\section{b. Ngarak Pasar}

Malam hari setelah dilangsungkan akad nikah, dilaksanakan upacara ngarak pasar. Saat ngarak pasar, rombongan keluarga mempelai laki-laki (penganten lanang) yang terdiri dari orang kedua orang tuanya.Sanak keluarga serta kerabat dekat datang berkunjung ke rumah orang tua mempelai perempuan.

Dalam tahapan upacara ngarak pasar ini, diarak dengan diiringi puji-pujian kepada Nabi SWA (Syarafat Anam). Tujuan ngarak penganten ini untuk memberitahukan kepada masyarakat bahwa si bujang dan sigadis sudah ada yang punya, jadi tahapan ini tifak lepas dari kebudayaan Islam..

Rombongan membawa nampan beralaskan kain sutra, diatas nampan diletakkan sebilah keris pusaka nenek puyang. Dalam banyak suku bangsa, keris merupakan benda upacara yang dipakai dalam hal menjalankan upacara-upacara keagamaan.

Nampan tempat diletakkannya keris,ditaburi bunga harum mewangi dan berwarna warni.Rombongan di arak berjalan menuju rumah mempelai wanita dengan diiringi musik gambus,mandolin dan lain-lain.

\section{c. Munggah}


Upacara munggah merupakan puncak dari tahapan adat dalam suatu proses perkawinanmasyarakat Palembang. Saat munggah kedua mempelai disandingkan dan dinobatkan menjadi raja dan ratu sehari. Kebalikannya dari akad nikah yang dilaksanakan di rumah pengantin pria makaupacara munggah dilaksanakan di rumah kediamam pengantin wanita.

Yang perlu diperhatikan setelah mengadakan akad nikah adalah mengadakan Walimatul 'urs karena Islam menganjurkannya seperti sabda Nabi SAW:"Adakan walimatul 'urs walaupun hanya menyembelih seekor kambing."

Islam menganjurkan untuk mengadakan walimatul'urs (resepsi, syukuran pernikahan)dengan memberikan jamuan makan kepada keluarganya,kawan-kawannya dan orang-orang miskin. Acara itu sengaja diadakan untuk mensyukuri dan mengakui karunia Allah SWT.

Disunnahkan mengadakan walimatul 'urs bagi yang mampu mangadakan pada hari kedua dari pernikahan dan dibolehkan memperlambat sampai hari ketujuh. Dibolehkan juga tidak menyediakan kambing sebagai jamuan makannya. Hendaknya jangan berlebihan dalam jamuan makan agar tidak mubazir.

Seseorang tidak perlu memaksakan diri ketika mengadakan walimatul 'urs, tetapi boleh mengeluarkan apa saja semampunya, karena Allah SWT tidak akan memaksakan seseorang, kecuali dalam batas kemampuannya.

Walimatul 'urs harus diadakan, meskipun hidangannya lebih sederhana dari makanan kedua mempelai. Dalam mengadakan walimatul 'urs jangan sampai menyuguhkan makanan yang enak, tetapi tidak mengundang orang miskin, karena disunnahkan tidak hanya mengundang orang-orang kaya dan meninggalkan orang-oran miskin, Nabi SAW bersabda:

"Seburuk-buruk makanan adalah sebuah walimah yang hanya mengundang orangorang kaya, tanpa orang miskin."

(Al-Jami' ash-Shagir,2353, hadits dhaif).

Mengadakan upacara pernikahan, menurut Islam hukumnya sunnah. Karena ia termasuk yang mulia dan perlu dihadiri oleh orang-orang baik dan terkemuka. Mereka berkumpul untuk mengungkapkan rasa syukur dan memohon kesuksesan dan kabahagiaan.

Tahap ini disebut juga acara puncak. Acara dimulai dengan kedatangan rombongan keluarga pengantin pria sambil membawa sejumlah barang antaran, 12 macam, yang berisi tiga set kain songket, kain batik Palembang, kain jumputan, kosmetik, buah-buahan, hasil bumi, aneka kue, uang dan perhiasan sambil diiringi dengan bunyi rebana. Setibanya di rumah pengantin wanita, ibu pengantin wanita membalutkan selembar kain songket motif lepus ke punggung pengantin pria lalu menariknya menuju kamar pengantin wanita, disebut acara gendong anak mantu. Sesampainya di depan pintu kamar, dilakukan acara ketok pintu dengan didampingi utusan yang dituakan, disebut tuggu jero. Setelah pintu dibuka, pengantin pria membuka kain selubung yang menutupi wajah istrinya yang disebut acara buka langse. Lalu dilakukan acara suapan dimana orangtua pengantin wanita menyuapi dengan nasi ketan kunyit dan ayam panggang. Kemudian diadakan acara cacap-cacapan yaitu orangtua pengantin pria mencacap/mengusap ubun-ubun kedua pengantindengan air kembang setaman sebagai tanda pemberian nafkah terakhir. Setelah 
itu acara sirih panyapo dimana pengantin wanita memberikan sirih pada suaminya sebagai perlambang dalam hidup keluarga mereka akan saling memberi dan menerima. Terakhir, diadakan upacara timbang adat yaitu topi pengantin pria ditimbang sebagai simbol bahwa mereka akan seia sekata menjalani kehidupan perkawinan.

Upacara munggah merupakan puncak dari tahapan adat dalam suatu proses perkawinanmasyarakat Palembang. Saat munggah kedua mempelai disandingkan dan dinobatkan menjadi raja dan ratu sehari dan dilaksanakan di rumah kediamam pengantin wanita.Yang perlu diperhatikan setelah mengadakan akad nikah adalah mengadakan Walimatul 'urs karena Islam menganjurkannya seperti sabda Nabi SAW:"Adakan walimatul 'urs walaupun hanya menyembelih seekor kambing."

Orang-orang yang mampu dianjurkan ikut andil dalam menyediakan jamuan makan bagi memepelai. Begitupun seorang yang diundang menghadiri jamuan makan,maka ia wajib mendatanginya untuk menyenangkan hati yang mengundang,mengikuti sunnah dan menguatkan tali hubungan. Jika ia tidak sempat hadir maka ia menyampaikan alasan Uzur (penyebab ketidakhadiran)nya.

Rasullullah bersabda:

"Jika seorang diantara kalian diundang menhadiri jamuan makan,maka hadirilah."

Disunnahkan juga memberi ucapan selamat dan doa seperti doa diatas kepada pengantin wanita.

Diriwayatkan bahwa Rasullullah SAW memberi ucapan selamat dan doa bagi kedua mempelai yang telah menikah. Doa itu memohonkan berkah dan kebaikan bagi keduanya, seperti yang disebutkan bahwa doa Rasullullah SAW adalah sebagai berikut: "Semoga Allah memberi berkah kepadamu dan mengumpulkan kalian berdua dalam kebaikan."

Doa serta ucapan selamat bagi kedua mempelai boleh diucapakan dengan ucapan apa saja,tetapi mengikuti tuntunan Nabi SAW lebih membawa berkah dan kebaikan dan sekaligus untuk menghidupkan syiar Islam.

\section{e. Ngobeng dan ngidang}

Makanan yang dihidangkan untuk para tamu dibawa dengan cara ngobeng (estafet), sedangkan makanan yang disuguhkan kepada tamu disajikan dengan cara ngidang, setiap hidangan cukup untuk delapan orang.

Angka delapan dalam masyarakat Melayu Palembang mengandung filosofi pembagian waktu sehari semalam. Waktu 24 jam maka ada tiga bagian yaitu, delapan jam untuk beribadah kepada Allah SWT, delapan jam untuk bekerja dan delapan jam untuk beristirahat.

Dalam kehidupan sosial dan kemasyarakatan mengandung nilai kerja sama dan kegotongroyongan. Selain itu juga dapat menjalin tali silaturahmi pada saat makan berkumpul bersama dalam satu hidangan dan juga nilai saling menghargai.

Mengadakan upacara pernikahan, menurut Islam hukumnya sunnah. Karena ia termasuk yang mulia dan perlu dihadiri oleh orang-orang baik dan terkemuka. Mereka berkumpul untuk mengungkapkan rasa syukur dan memohon kesusesan dan kabahagiaan. Dalam upacara akad nikah Mayarakat Melayu Palembang diwarnai dengan ucapan-ucapan 
yang benar dan baik, termasuk juga pesan-pesan takwa dan iman dalam pidato upacara akad nikah, khususnya yang pernah dicontohkan dari Nabi Muhammad SAW.

\section{a. Beratip}

Penulis berkesempatan mengikuti rangkaian upacara adat pernikahan sampai terlaksananya rangkaian Ratip Samman, yang pesertanya didatangkan dari Masjid Agung Palembang. Beratip atau Ratip Samman merupakan acara penutup dari seluruh rangkaian kegiatan prosesi yang telah dilakukan.

Dalam beratip berkumpullah para laki-laki dewasa yang melakukan kegiatan membacakan kalimat-kalimat tauhid, ayat-ayat suci al qu'ran dan zikir-zikir yang bersumber dari ajaran tariqat Sammaniya. Pencetus tariqat samaniya ini adalah Syeckh Muhammad Abdul Karim Saman yang disebarkan oleh muridnya Syeckh Abdush Somad Al-Palimbani. Ratib Samman telah mentradisi sejak masa kesultanan Palembang Darussalam hingga saat ini. Hampir setiap masjid-masjid tua di Palembang mengamalkan Ratib Sammam secara rutin.

Acara Ratib Samman ini wujud rasa syukur kepada Allah SWT atas segala rahmat dan berkah yang telah diberikan sehingga rangkaian acara prosesi pernikahan berjalan dengan lancar. Selain itu setelah Ratib Samman diadakan doa keselamatan tetutama bagi dua pengantin barudan juga kedua keluarga yang telah bersatu dalam ikatan perkawinan.

\section{Tahapan Adat Setelah Upacara Perkawinan.}

Malam pernikahan atau malam pertama merupakan malam yang mulia dalam kehidupan sebuah sebuah rumah tangga. Karena akan diingat sepanjang umur,agar segala harapan baik yang direncanakan pada malam itu dapat diingat dan dipenuhi satu persatu.

Tahapan prosesi adat pernikahan masyarakat Melayu Palembang diselenggarakan dalam tujuh hari tujuh malam. Jadi setelah akad nikah biasanya belum diadakan malam pengantin dan pengantin belum diperbolehkan bersama dalam satu kamar. Sedangkan malam pengantin biasanya diatur oleh tunggu jero pada tahapan adatpenganten baeanatau malam penganten.

Sebelum sampai pada tahap penganten baean atau malam penganten masih ada tahapan prosesi lagi yaitu:

a. Nganter bangking

Merupakan tahapan adat yang dilakukan pada malam hari setelah upacara munggah. Tahapan ini adalah mengantarkan pakaian pengantin laki-laki rumah pengantin wanita

\section{b. Tunjung tenga kambang}

Acara adat ini dilaksanakan sehari setelah munggah dan biasanya pada hari senin menjelang sore sekitar pukul 14 dan khusus diperuntukan bagi kaum wanita.

c. Ngale Turon

Setelah malem nganter bangking, pada malam berikutnya kedua pengantin kembali dimunggahkan di rumah pengantin pria, dalam acara ini disajikan hiburan theater tradisional seperti dul muluk yang mentas semalam suntuk.Dari pihak pengantin wanita hadir bujang dan gadis, yang datang pada malam ngale turon disebut nyanjoi. 
Dua hari sesudah munggah biasannya dilakukan acara nyemputi. Pihak pengantin lelaki datang dengan rombongan menjemputi pengantin untuk berkunjung ketempat mereka, sedangkan dari pihak wanita sudah siap rombongan untuk nganter ke pengantin. Pada masa nyemputi penganten ini di rumah pengantin lelaki sudah disiapkanacara keramaian (perayaan). Perayaan yang dilakukan untuk wanita-wanita pengantin ini baru dilakukan pada tahun 1960-an, sedangkan sebelumnya tidak ada.

\section{e. Penganten Balek}

Tahapan ini adalah upacara adat untuk memulangkan pengantin pria dan wanita kembali ke rumah pengantin wanita setelah sebelumnya mereka menginap dua malam di rumah pengantin wanita. Pada saat penganten balek keluarga penganten pria memberikan dan membawakan peralatan dapur, yang disebut dengan gegawaan.

\section{f. Mandi Simburan}

Acara dimulai dengan doa yang dipimpin oleh ayah pengantin wanita, setelah itu sang ayah menyacapi kepala kedua pengantin dengan kembang tujuh warna, diikuti oleh ibu,wak,bibik dan keluarga serta kerabat dekat lainnya. Makna nyacapi ini adalah memberikan doa restu kepada kedua pengantin. Dilanjutkan dengan memandikan pengantin oleh kedua orang tua, lalu penganten saling memandikan dilanjutkan dengan yang hadir.

\section{g. Penganten baean/malam pengantin}

Pada malam-malam sebelumnya walaupun penganten sudah sah sebagai suami istri tetapi belum boleh tidur sekamar. Malam setelah mandi simburan baru mereka boleh tidur sekamar.Acara adat Penganten baean ini tetap dipandu oleh tunggu jero, sebelumnya tunggu jero telah memberikan petujnjuk kepada kedua pengantin apa yang seharusnya mereka lakukan pada malam penganten baean ini. Pada pagi harinya tunggu jero membimbing untuk sujudan kepad orang tua dan keluarga yang masih ada, dan mereka mengerti bahwa penganten telah melakukan kewajibannya.

\section{h. Syukuran}

Keluarga penganten wanita mengundang kerabat dekat untuk mengadakan acara syukuran karena kedua penganten telah dipertemukan dalam pernikahan.

\section{i. NyanjoiPenganten}

Nyanjoi dilakukan disaat malam sesudah munggah dan sesudah nyemputi. Biasannya nyanjoi dilakukan dua kali, yaitu malam pertama yang datang nyanjoi rombongan mudamudi, malam kedua orang tua-tua. Demikian juga pada masa sesudah nyemputi oleh pihak besan lelaki.Acara adat ini berarti membawa kedua pengantin berkunjung ke rumah sanak keluarga agar mereka lebih mengenal keluarga kedua belah pihak, dalam melakukan ini penganten didampingi oleh kedua orang tua.

j. Penganten tandang

Tahapan terakhir dalam rangkaian atau tahapan tata cara adat pernikahan Masyarakat Melayu Palembang adalah penganten tandang, disini kedua pengantinmendatangi rumah kerabat dan keluarga tanpa didampingi ibu masing-masing pengantin.

k. Ngater Penganten 
Pada masa nganter penganten oleh pihak besan lelaki ini, di rumah besan wanita sudah disiapkan acara mandi simburan. Mandi simburan ini dilakukan untuk menyambut malam perkenalan antara pengantin lelaki dengan pengantin wanita. Malam perkenalan ini merupakan selesainya tugas dari tunggu jero yaitu wanita yang ditugaskan untuk mengatur dan memberikan petunjuk cara melaksanakan acara demi acara disaat pelaksanaan perkawinan. Wanita tunggu jero ini dapat berfunsi sebagai penangawal atau penjaga keselamatan berlangsungnya seluruh acara perkawinan yang kemungkinan akan ada gangguan dari orang yang tak senang.

Dalam upacara perkawinan adat Palembang, peran kaum wanita sangat dominan, karena hampir seluruh kegiatan acara demi acara diatur dan dilaksanakan oleh mereka. Pihak lelaki hanya menyiapkan "ponjen uang". Acara yang dilaksanakan oleh pihak lelaki hanya cara perkawinan dan acara beratib yaitu acara syukuran disaat seluruh upacara perkawinan sudah diselesaikan.

Suatu masa peralihan yang ada dan hampir seluruh masyarakat dunia dan dalam sebuah kebudayaan adalah peralihan dari tingkat hidup remaja ke tingkat hidup berkeluarga melalui proses perkawinan. Demikian pula dengan masyarakat Melayu Palembang peralihan dari tingkat hidup remaja ke tingkat hidup berkeluarga dianggap penting mengingat peralihan tingkat hidup ini bukan hanya berarti peralihan lingkungan sosial ke lingkungan sosial lainnya. Namun yang lebih penting adalah bahwa peralihan tingkat hidup ini disertai pula peningkatan peran dan tanggung jawab moral dan sosial baik dalam kehidupan berkeluarga maupun di dalam hidup bermasyarakat.

Oleh karena itu, jika seorang individu anggota keluarga masyarakat Palembang telah menentukan untuk beralih ke tingkat hidup berkeluarga, maka akan diadakan pesta dan upacara untuk merayakan.Walaupun sebagian besar masyarakat Palembang tidak lagi mengikuti tata cara adat perkawinan suku Palembang, namum diantara keluarga bangsawan, pejabat dan masyarakat yang mempunyai kemampuan secara finansial masih ada yang melaksanakan tata cara adat ini.

Tata cara perkawinan masyarakat Melayu Palembang menurut adat harus melalui beberapa tahapan, namun pada saat ini kebanyakan masyarakat hanya melaksanakan empat tahapan saja,yaitu melamar,pertunangan,menentukan hari akad nikah dan resepsi atau pesta. Hampir tidak ditemukan lagi seoarang kepalak rasan melakukan madik.Saat ini bujang dan gadis dapat menentukan sendiri siapakah calon pasangan mereka.Bujang gadis masa sekarang pada umumnya mereka berkenalan, bergaul saling memahami kepribadian masing-masing.

Demikianpun dalam pelaksanaan akad nikah dapat dilakukan di rumah orang tua laki-laki maupun orang tua wanita. Pada waktu pelaksanaan akad nikah,calon penagntin wanitapun sudah mulai dihadirkan.

Seiring dengan perubahan dan penyederhanaan yang terjadi,jumlah dan jenis gegawan pun telah berubah.Jika berpatokan pada adat,gegawaan haruslah berjumlah empat puluh nampan dan dibawa oleh empat puluh orang juga.Pada saat ini jumlahnya dapat saja berkurang atau bertambah,namun lebih sering berkurang namun bisa saja kualitas gegawaan lebih baik. Semua berdasarkan mufakat dan pengertian kedua belah pihak. 
Perubahan lain yang terjadi dalam penentuan akad nikah. Menurut adat akad nikah yang baik haruslah pada hari jumat sebelum matahari terbenam. Dalam perkembangannya hari akad nikah ditentukan oleh kedua belah pihak dengan mempertimbangkan kesibukankesibukan kedua belah pihak serta pihak-pihak terkait.

Pelaksanaan tata cara adat pernikahan masyarakat Melayu Palembang sangatlah menyita waktu, tenaga dan biaya serta melibatkan banyak orang, baik keluarga, kerabat maupun para jiran tetangga. Faktor kemampuan ekonomi yang berhubungan dengan pangkat dan kedudukan seseorang dalam masyarakat sangat erat hubungannya dengan pelaksanaan tata cara adat perkawinan.

Tata cara adat pernikahan sekarang ini untuk yang berasal dari kalangan kelompok enomoni lemah dan menengah tidak dapat melaksanakan perkawinan secara utuh. Sedangkan bagi golongan masyarakat yang mampu secara ekonomi, tidak melaksanakan karena berprinsip secara efektif dan effisien sehingga menyederhanakan tata cara adat pernikahan baik dari segi nilai atau makna.

\section{B. Pernikahan Masyarakat Melayu Palembang Dalam Islam}

Islam dengan syariahnya yang agung dan sistemnya yang komprehensip telah menetapkan kaidah-kaidah dan hukum-hukum dalam pernikahan. Kaidah-kaidah itu dipegang teguh oleh masyarakat melayu Palembang. untuk itu apabila tatanan dalam Islam di patuhi dan dijalankan, niscaya pernikahannya akan diwarnai rasa saling memahami,saling toleransi dan saling mencintai. Keluarga akan berada dipuncak keimanan yang kokoh, akhlak yang lurus, tubuh yang sehat, akal yang matang dan jiwa yang tenang serta suci.

Modal pokok kehidupan pasangan suami adalah rasa kasih sayang. Dari modal pokok inilah timbul rasa saling mencintai di jalan Allah,saling setia,saling bekerja sama.Karena didasari cinta maka rela saling membahagiakan dan saling melindungi. Keduanya disatukan oleh Islam dalam ikatan perkawinan yang didasari ingin mencari ridha Allah

Agar rumah tangga dapat berdiri dengan kokoh dalam memilih pasangan bagi masyarakat melayu Palembang, lebih mengutamakan kriteria agama yang dibandingkan harta, keturunan dan kecantikan. Hal ini karena agama merupakan pondasi yang kokoh dalam perkawinan, sedangkan segala sesuatu selain agama hanyalah soal duniawi semata yang bersifat fana. Tak ada yang tersisa untuk manusia dihadapan Allah kecuali agama dari istrimu.

Karena itu, Nabi SAW membimbing orang-orang yang akan menikah untuk mengambil wanita yang memiliki kualitas agama yang baik, agar istri dapat melaksanakan kewajibannya dengan sempurna, khususnya dalam memenuhi hak suami, hak anak-anak dan hak rumah tangga. Itulah sebabnya Rasullaulah bersabda :

"Dunia itu kenikmatan dan sebaik-baiknya kenikmatan dunia adalah istri salehah" (Riwayat Muslim,Kitab ar-Ridha,no.1467).

Urusan perkawinan dalam masyarakat melayu Palembang dilaksanakan dengan berbagai upacara yang kental dengan kehikmadan, nuansa keagamaan sering menjiwai bertemunya dua insan berlainan jenis untuk membentuk suatu keluarga. Untuk itu nuansa 
agamawi sering menjadi alur urat yang dominan. Dari lembaga perkawinan, maka terbentuk sebuah kesatuan keluarga.

Perkawinan pada masyaraktat melayu Palembang mempunyai hubungan yang erat sekali dengan agama sehingga bukan saja mempunyai unsur lahir/jasmani, tetapi unsur juga batin/rohani. Masing-masing tatanan masyarakat memiliki karakter yang berbedabeda dalam memberikan nilai pengharapan terhadap lembaga perkawinan. Begitupun pada masyarakat Melayu Palembang dalam memberikan penghargaan dan penilaian yang dipegang serta dipatuhi umumnya didasarakan pada unsur agamawi yaitu Islam yang dipeluk oleh masyarakat melayu Palembang. Maka tidak mengherankan manakala perkawinan sebagai salah satu sendi kehidupan kelompok akan memperoleh pengaturan yang acap kali sarat dengan berbagai norma ketat yang dijunjung tinggi kadar kesucian.

\section{Islam Dan Adat Budaya Pernikahan Masyarakat Melayu Palembang}

Keberadaan melayu identik dengan nafas Islam, sehingga konstruksi syarat sahnnya nikah pada masyarakat Melayu Palembang sangatlah terasa nuansa Islamnya, dimana terdapat juga akulturasi dengan kebiasaan masyarakat Palembang seperti lamar-lamaran dengan membawa gegawan dan ada juga uang asap untuk melaksanakan resepsinya.

Lahirnya hukum adat ini mengingat para pejuang yang menyebarkan Islam di negara Indoensia ini sebagai cambuk pendekatan, kenapa dikatakan seperti itu, karena hukum adat ada sebagai membantu hukum Islam masuk kemasyarakat setempat, bukan untuk dipakai selamanya, apalagi apabila hukum adat tersebut bertentangan dengan hukum Islam, namun belakang ini hukum adat seolah-olah mengakar dan mendarah daging menjadi hukum yang permanen, dari sini teori receptie muncul kembali yang bertujuan bahwa hukum Islam bisa dipakai kalau itu bisa diterima di adat setempat.

Perkembangan yang berlaku dalam tatanan sosial masyarakat selalu diringi dengan perkembangan pemikiran. Disamping itu, nilai rasa berkaitan dengan kelembutan, kehalusan dan keindahan turut mengiringi perkembangan ini. Terbentuklah sistem budaya dan sistem sosial yang terkait dengan perkembangan dan perubahan, sehingga menjadi semacam tatanan tersendiri di tiap masyarakat pendukung kebudayaan.

Adat perkawinan Palembang adalah suatu pranata yang dilaksanakan berdasarkan budaya dan aturan Palembang. Melihat adat perkawinan Palembang, jelas terlihat bahwa busana dan ritual adatnya mewariskan keagungan serta kejayaan raja-raja dinasti Sriwijaya yang mengalaimi keemasan berpengaruh di Semenanjung Melayu berabad silam. Pada zaman kesultanan Palembang berdiri sekitar abad 16 lama berselang setelah runtuhnya dinasti Sriwijaya, dan pasca Kesultanan pada dasarnya perkawinan ditentukan oleh keluarga besar dengan pertimbangan bobot, bibit dan bebet. Pada masa sekarang ini perkawinan banyak ditentukan oleh kedua pasang calon mempelai pengantin itu sendiri. Untuk memperkaya pemahaman dan persiapan pernikahan, berikut ini uraian tata cara dan pranata yang berkaitan dengan perkawinan Palembang.

Pernikahan adat dan budaya Melayu Palembang, bernafaskan Islami hal ini bisa dilihat dari tata cara pernikahan dan rukun menikah dalam masyarakat Melayu Palembang, misalnya usia pengantin yang sudah akil baligh,ada persetujuan wali nikah adanya saksi ijab qobul. 
Adat perkawinan melayu Palembang memang menggunakan hukum Islam namun ada beberapa koreografi sendiri seperti pra nikah dan setelah nikah. Dalam hal pra nikah bisa kita lihat dengan silaturahmi keluarga mempelai pria kepada keluarga mempelai wanita untuk dapat dikawini,yang akan dilanjutkan dengan lamar-lamaran ato mutus kato,yang tujuannya untuk mengetahui bahwa keluarga telah sepakat kapan akan mengadakan pernikahan tersebut.

Pernikahan di Palembang sesuai dengan adat melayu yang bernafaskan keislaman, kalau kita lihat konsepsi hukum adat untuk tercapainya suatu keseimbangan, karena prinsip yang digunakan untuk mengembalikan kondisi kepada keadaan semula atau tetap. Maksudnya misal dalam hal memberikan uang asap, tujuannya bukanlah untuk menjual belikan mempelai wanita, akan tetapi untuk meringankan keluarga mempelai wanita apabila akan melaksankan resepsi pernikahan di tempat mempelai wanita, selain itu juga meringankan beban keluarga dari mempelai wanita sehubungan anaknya akan mengikuti suaminya tinggal karena tentunya amatlah berat ketika anak perempuannya harus lebih memilih tinggal dengan suaminya tersebut.

\section{Penutup}

Dengan berpedoman kepada Al-Quran dan hadits sebagai dasar nilai-nilai yang dianut dalam masyarakat, maka suku Melayu Palembang membentuk warna sendiri dalam mengembangkan adat-istiadat pernikahan. Secara kebudayaan masyarakat Palembang mewarisi nilai-nilai budaya Palembang Darussalam yang kuat menjalankan syariat Islam bermazhab syafei dan umumnya menjalankan tarekat Samaniyah.

Hukum hukum adat yang ada di negara kita adalah hukum yang sesuai dengan perkembangan masyarkat Islam di Indonesia, adat pernikahan masyarakat melayu Palembang pada pelaksanaannya merupakan aplikasi dari teori hukum Islam.

Implikasi Pernikahan dalam masyarakat Melayu Palembang bahwa pernikahan dalam Islam tidak bisa terpisah dari kehidupan masyarakat Palembang yang mengabdi kepada Allah, yang mengikuti petunjuk-petunjuk dan syariat Allah SWT di muka bumi. Islam menganjurkan setiap individu muslim mancari dan memilih calon pendamping hidup yang cocok dan yang bagus agamanya serta budi pekertinya, agar terbinalah rumah tangga muslim yang akan menjadi salah satu simbol-simbol adat yang digunakan secara substansi selaras dengan nilai-nilai Islam. Dari mulai proses memilih calon dan madik yaitu melihat kriteria bibit, bebet dan bobot sebagai ukuran atau parameter penilaian.

Implikasi hukum Islam dalam perkawinan masyarakat Melayu Palembang dengan Undang-Undang tentang perkawinan dalam pelaksanaannya sudah sejalan, sesuai dengan pijakan dan rujukan. Sedangkan yang menjadi pijakan dan rujukan dalam Undang-undang tentang perkawinan adalah Al Quran, Al Sunnah, Qaidah Fighiyah dan Konsensus (Ijma) Umat Islam di Indonesia.

\section{Daftar Pustaka}

Assegaf, Abd Rahman. (2005), Studi Islam Kontekstual, Elaborasi Paradigma Baru Muslim Kaffah, Yogyakarta: Gama Media. 
Ash-Shiddieqy, T.M, (1975), Falsafah Hukum Islam. Jakarta: Bulan Bintang

Basyir, Ahmad Azhar, (1990), Hukum Perkawinan Islam, UII Press, Yogyakarta.

Cresswel, JohnWl,(1995) Qualitative Inquiry and Research Design Choosing among Five traditions London: New delhi Sage Publication Intra. Educational and Profesional Published.

Hakim, Rahmat, (2000), Hukum Perkawinan Islam, Bandung: Pustaka Setia.

Hamka, (1974), Antara Fakta dan Khayal, Jakarta: Bulan Bintang.

Hasan, Djuhaendah, (1988) Hukum Keluarga Setelah Berlakunya 1/1974 (menuju hukum keluarga Nasioanal), Bandung: Amriko.

Hazairin (1995), Hukum Islam dan Masyarakat, Jakarta: Bulan Bintang.

Herusatoto,Budiono, (2005), Simbolisme dalam Budaya Jawa, (Yogyakarta Hanindita Graha Widia,

Idi, Abdullah, (2015), Dinamika Sosiologis Indonesia, Agama dan Pendidikan dalam Perubahan Sosial, Yogyakarta: PT.LKIS Pelangi Aksara.

Izomiddin,(2014) Pemikiran dan Filsafat Hukum Islam, Yogyakarta: IDEA Press, Jalaluddin dan Sugiono, Pedoman Penulisan Disertasi, Palembang : Pasca Sarjana IAIN Raden Fatah Palembang.

KGPAA Mangkunegara IV, (2010), Analisis Hukum Islam Terhadap Konsep Kafa'ah Kompilasi Hukum Islam, Jakarta: Fakus Media.

Kuntowijoyo, (2000) Paradigma Islam Interpretasi Untuk Aksi Yogyakarta: Ittaka Press,

Mardjoned, Ramlan, (2000), Keluarga Sakinah: Rumahku Surgaku, Jakarta: Media Da'wah,

Rivai, Ahmad Husin, (1998) Reformasi Intelektual Islam :Pemikiran Hassan Hanafi tentang Reakualisasi Tradisi Keilmuan Islam, Yogyakarta: Ittaka Press.

Schur, Edwin M, (1986), Law and Society a Sociological View, New York: Random House.

Setiady, Tolib. (2009) Intisari Hukum Adat Indonesia (Dalam Kajian Kepustakaan), Bandung: Alfabeta.

Syarifudin, Amir (2009), Hukum Perkawinan Di Indonesia, Jakarta: Kencana Prenada Media Grup. 